\title{
VAHENDAMATA JA VAHENDATUD NARRATIIV LASTE KÕNEARENGU HINDAMISEL
}

\author{
Piret Soodla, Eve Kikas, Renate Pajusalu, \\ Aive Adamka, Sirli Parm
}

Ülevaade. Artikkel käsitleb 162 eakohase kõnearenguga ja 27 alakõnega 6-7-aastase lapse kolmel viisil jutustatud suulisi narratiive vahendamata narratiive ilma eelneva narratiivi mudelita, eelnevalt mudeldatud vahendamata narratiive ning vahendatud narratiive. Analüüs hõlmab narratiivide mikrostruktuuri (lausungite keskmist pikkust, grammatilist õigsust) ning makrostruktuuri (infoüksuste hulka, komplekssust). Eesmärgiks on selgitada, missugusel viisil koostatud narratiivid eristavad kõnearengu mahajäämust eakohasest arengust kõige paremini. Tulemustest selgub, et jutustamisoskuse hindamiseks narratiivi mikrostruktuuri tasandil sobivad kõigil kolmel viisil jutustatud narratiivid. Makrostruktuuri tasandil on parimaks hindamisvahendiks vahendatud narratiiv, millele järgneb eelnevalt mudeldatud vahendamata narratiiv.*

Võtmesõnad: keeleline areng, kõnepuuded, narratiiv, suuline keel, süntaks, morfoloogia, tekstistruktuur, eesti keel

\section{Sissejuhatavat}

Artikkel analüüsib üht kõnetegevuse olulist funktsiooni - narratiivi - ja selles peegelduvat kõnearengu taset. Mõistet narratiiv on keeleteaduses defineeritud erinevalt. Näiteks William Labovi järgi (1972: 359-360) on narratiiv keelekasutuse meetod, mille abil minevikus aset leidnud sündmusi edastatakse verbaalse lausejärjendina. Jerome Bruner (1985: 98-99) on aga narratiivi defineerinud kui ühte mõtlemise viisi, milles opereeritakse tegelaste kavatsuste ja ajaliselt järjestatud toimingutega, vastandudes seejuures teisele, loogilis-teaduslikule mõtlemisviisile. Hoolimata mõneti erinevatest definitsioonidest ollakse siiski ühel meelel, et narratiivne tekst jutustab tüüpiliselt tegelaste (kelleks võivad olla nii inimesed, loomad kui

* Artikkel on valminud Eesti Teadusfondi grantide nr 7388 ja 7492 toel. 
ka väljamõeldud olendid) tegevustest ja/või tunnetest ja mõtetest ajalises mõõtmes. Käesolevas artiklis kasutame narratiivi sünonüümina ka terminit jutustus.

Narratiive peetakse rikkalikuks keelematerjaliks keeleteaduslikes, psühholoogia- ning kõnepatoloogiaalastes uurimustes. On leitud, et narratiivid eristavad hästi eri vanuses ja keeleliste võimetega lapsi (Liles 1987, Merritt, Liles 1987, Reuterskiöld Wagner jt 1999, Scott, Windsor 2000, Botting 2002, John jt 2003, Ukrainetz jt 2005). Paljudes uurimustes on osutatud erinevustele eakohase kõnearenguga (EK) ja alakõnega $(\mathrm{AK})^{1}$ laste iseseisvates ehk vahendamata narratiivides (nt Norbury, Bishop 2003, Pearce jt 2003, Fey jt 2004, Reilly jt 2004, Schneider jt 2006) ning ümberjutustustes ehk vahendatud narratiivides (nt Hayward jt 2007, Pankratz jt 2007). Tulemusi on aga raske üldistada keelte, uuritavate laste vanuse, uuringu protseduuri, hindamisvahendite ja uurimisobjektide erinevuste tõttu. Vahendamata ja vahendatud narratiive võrdlevaid uurimusi on senini läbi viidud vähe (Merritt, Liles 1987, 1989, Liles jt 1995, Reuterskiöld Wagner jt 1999, Botting 2002) ning tehtud järeldused on üsna vastuolulised. Puudub selgus, mil viisil koostatud jutustused eristavad eakohast ja mahajäänud kõnearengut kõige paremini. Logopeedilises töös on nimetatud teadmised aga olulise väärtusega.

Käesolevas uurimuses võrdleme 6-7-aastaste EK ja AK laste kolmel erineval viisil jutustatud narratiive (vahendamata narratiiv ilma eelneva narratiivi mudelita ja eelneva mudeliga ning vahendatud narratiiv). Eesmärgiks on selgitada, mis viisil koostatud narratiivid eristavad alakõnet eakohasest kõnearengust kõige paremini.

\section{Narratiivi mikrostruktuur eakohase arenguga ja alakõnega lastel}

Tekst on üles ehitatud hierarhiliselt kahel - mikro- ja makrostruktuuri - tasandil (van Dijk, Kintsch 1983). Nendest lähtuvalt analüüsitakse laste jutustavaid tekste ka kõnepatoloogiaalastes uurimustes (Hughes jt 1997: 111). Mikrostruktuur moodustub teksti väiksematest üksustest, s.t sõnadest, lausungitest ning lausungitevahelistest seostest. On leitud, et mikrostruktuuri näitajad eristavad hästi $\mathrm{AK}$, iseäranis spetsiifilise kõnearengu puudega ${ }^{2}$ lapsi eakohase kõnega lastest (Liles jt 1995, Scott, Windsor 2000). Järgnevas ülevaates käsitleme narratiivi lausungite keskmist pikkust, grammatilist õigsust ning lausungitevahelist sidusust, mis on vaatluse all ka töö uurimuslikus osas.

Pikki lausungeid peetakse üldjuhul iseloomulikuks süntaktiliselt keerukale väljendusele (Scott, Windsor 200o). Inglise keelel põhinevates uurimustes on leitud, et laste vanuse kasvades muutuvad pikemaks ka jutustustes kasutatud lausungid (Justice jt 2006, Tilstra, McMaster 2007), samuti eristab lausungite keskmine pikkus AK laste jutte EK laste omadest nii vahendamata (Scott, Windsor 2000, Bishop, Donlan 2005) kui ka vahendatud narratiivides (Hayward jt 2007).

Grammatikavigu jaotatakse süntaksivigadeks (nt obligatoorsete lauseliikmete väljajätt, vale sõnajärg) ja morfoloogiavigadeks (mingi tunnuse, lõpu või liite

\footnotetext{
Alakõne ehk kõnearengu üldise mahajäämuse korral avalduvad semantikapuuded, vanusnormile ei vasta kõik keeletasandid (sõnavara, grammatika, foneemid). Eristatakse kolme tasandit: esimene tasand (lalinkõnest kuni agrammatilise lauseni), teine tasand (agrammatilisest lausest kuni primitiivse tekstini), kolmas tasand (alakõne jääknähud, sh primitiivne tekst ja lause) (Karlep 1997: 11).

2 Spetsiifilise kõnearengu puude (ingl specific language impairment) korral esineb oluline mahajäämus eakohasest kõnearengust. Tegemist on esmase kõnepuudega, s.t alakõne ei tulene vaimsest alaarengust, kuulmislangusest, neuroloogilistest haigustest, keskkonna mõjudest, "emotsionaalsetest häiretest" (millena enamasti peetakse silmas autistlikke häireid) ega artikulatsiooniaparaadi füüsilistest puuetest (Bishop 1997: 32-34).
} 
ärajätmine, asendamine, lisamine). Eesti keele spetsiifikast tulenevalt lisanduvad morfofonoloogilised vead, mis avalduvad morfeemivariandi (käändelõpu, tunnuse, liite või tüve) vales valikus või moonutamises (Padrik 2006). Inglise keelel põhinevad uurimused on näidanud, et kõnearengu käigus grammatikavead vähenevad (Tilstra, McMaster 2007) ning need on sobivaks näitajaks EKja AK laste jutustuste eristamisel (Scott, Windsor 2000, Norbury, Bishop 2003, Pearce jt 2003, Fey jt 2004). Kuna muutemorfoloogia omandamine on keelespetsiifiline protsess, olles mõjutatud nii sisendkeele sagedustest ja eelistustest kui ka morfoloogilistest, fonoloogilistest ning morfosüntaktilistest teguritest (Argus 2008: 41), ei saa teistes keeltes saadud tulemusi siiski otseselt üle võtta.

Lausungid on tekstis omavahel semantiliselt ja lingvistiliselt seotud. Leksikaalsetest vahenditest kasutatakse enam otsest kordust, sünonüüme, antonüüme, eri üldistusastmega sõnu (hüperonüüme), samatüvelisi tuletisi ja liitsõnu, temaatilisi sõnarühmi, ase-, määr- ja arvsõnu. Grammatilisteks vahenditeks on tegusõnade samad ajavormid, sõnajärg, sidendid, üldlaiendid ja sarnased lausekonstruktsioonid (Karlep 2003: 266). Sidusust peetakse üldjuhul teksti mikrostruktuuritasandi tunnuseks (Hughes jt 1997: 145), v.a lausetevahelisi sidendeid, mis suhestuvad enam makrostruktuuriga (Liles jt 1995). Leksikaalsetest vahenditest kasutavad eesti lapsed koolieelses eas ja algklassides valdavalt otsest kordust ja asesõnu, enamkasutatavateks sidenditeks on ja, siis ning ja sïs (Pajuste 2007, Ruul 2009). Nii inglise kui ka eesti keeles on leitud, et arengu käigus õigesti kasutatud sidusvahendite sagedus tõuseb ja mitmekesistub (Peterson, Dodsworth 1991, Shapiro, Hudson 1991, Ruul 2009) ning AK laste jutud sisaldavad tavalastega võrreldes oluliselt vähem sidusvahendeid (Liles 1987, Ripich, Griffith 1988, Ruul 2009). Ümberjutustustes on leksikaalne sidusus (objektile viitamine) tugevam kui vahendamata tekstides, seda nii eakohase kui mahajäänud kõnearengu korral (Ripich, Griffith 1988, Pajuste 2007).

\section{Narratiivi makrostruktuur eakohase arenguga ja alakõnega lastel}

Makrostruktuuri all peetakse silmas teksti üldist sisulist ülesehitust. Makrostruktuur viitab otseselt teksti terviklikkusele. Et tekst oleks terviklik, peab jutustaja edastatava informatsiooni organiseerima ajaliselt ja põhjuslikult seotud järjendiks, mis on tähendusrikas nii kõneleja enda kui kuulajate jaoks (Shapiro, Hudson 1991). Narratiivi terviklikkusele aitavad kaasa mitmed struktuurielemendid, nt traditsioonilised jutustuse algus- ja lõpumarkerid, tegevuse aja ja koha ülevaade, tegelaste kirjeldused, tegevused, tegelastevaheline dialoog, eesmärgid, reaktsioonid, ettetulevad takistused, tegelase püüded neid ületada jne (Shapiro, Hudson 1991). Lisaks peetakse hea jutu tunnuseks jutustajapoolset vaatepunkti jutustatavale, s.t hinnanguid tegelaste, nende tegutsemise motiivide ja asetleidnud sündmuste kohta (Ukrainetz jt 2005).

Narratiivi makrostruktuuri analüüsiks on välja pakutud mitmeid mudeleid, millest levinuim on Nancy Steini ja Christine Glenni (1979) jutugrammatika mudel (ingl Story Grammar Model). Mudeli järgi koosnevad narratiivid teatud kindlat tüüpi informatsiooni sisaldavatest komponentidest, mis on omavahel seotud 
ajaliselt ja/või põhjuslikult. Jutustuse makrostruktuur koosneb taustakirjeldusest ja episoodide süsteemist. Taustakirjelduses tutvustatakse peategelasi ning kirjeldatakse sotsiaalset, füüsilist või ajalist konteksti, milles sündmused hakkavad aset leidma. Jutustus võib koosneda vaid ühest, enamasti siiski mitmest omavahel seotud episoodist. Episood koosneb kuuest komponendist: 1) käivitav sündmus, mis tekitab tegelasel lahendamist vajava probleemi; 2) sisemine vastus - käivitavast sündmusest tingitud tegelase reaktsioon (tunded, mõtted); 3) sisemine plaan - tegelase plaan probleemi lahendamiseks või olukorra muutmiseks; 4) tegevus - tegelase toimingud plaani täitmisel; 5) tagajärg - tegevuse otsene tagajärg; 6) reaktsioon tegelase reaktsioon tagajärjele. Struktuurilt kõige olulisemateks üksusteks peetakse käivitavat sündmust või sisemist vastust, eesmärgipärast tegevust ja tagajärge (Liles jt 1995). Vähemalt nimetatud kolme komponenti sisaldavat episoodi nimetatakse lõpetatuks. Ka ülejäänud komponendid annavad olulist informatsiooni, kuid pole narratiivi terviklikkuse aspektist hädavajalikud (Merritt, Liles 1987).

Kirjeldatud mudelil põhinevad paljud uurimused, kus on vaatluse all jutugrammatika komponentide esinemissagedus (nt Merritt, Liles 1987, John jt 2003) või lõpetatud ja lõpetamata episoodide osakaal narratiivis (nt Merritt, Liles, 1987, Ripich, Griffith 1988). Nimetatud meetodid ei ole aga osutunud efektiivseks alakõne diferentsiaaldiagnostikas (Liles jt 1995, Norbury, Bishop 2003). Phyllis Schneider jt (2006) soovitavad narratiivide makrostruktuuri hindamisel arvesse võtta kõikides jutugrammatika komponentides sisalduvat informatsiooni, mis autorite hinnangul võimaldab paremini eristada AK ja EK laste jutustusi. Paraku on AK ja EK laste narratiive nimetatud aspektist vähe uuritud ning saadud tulemused on vastuolulised: on leitud, et nii vahendamata kui ka vahendatud jutustustes on olulise informatsiooni hulk AK lastel oluliselt väiksem kui EK korral (Reutersköld Wagner jt 1999, Schneider jt 2006), kuid on ka tulemusi, kus nimetatud erinevusi ei leitud (Norbury, Bishop 2003).

Siiski on hea narratiiv midagi enamat kui keeleliselt korrektne, sidus ja sisult struktureeritud sündmuse edastamine. Et kuulaja tähelepanu saavutada ja oma mõtteid võimalikult täpselt edastada, kasutab oskuslik jutuvestja keelelisi ja mittekeelelisi vahendeid, nt häälitsusi, hüüatusi, rõhutamist, kordamist, küsimusi kuulajale, liialdusi ja fantaasiat, hinnanguid jm (Hughes jt 1997:132). Nende nn ekspressiivsete elementide kasutamine kõnearengu käigus sageneb ja mitmekesistub (Ukrainetz jt 2005). AK ja EK laste narratiivide võrdlusel pole aga üheste tulemusteni jõutud: erinevusi on leitud nii vahendamata (Reilly jt 2004) kui ka vahendatud jutustustes (Sleight, Printz 1985), kuid on ka uurimusi, kus erinevusi ekspressiivsete elementide kasutamisel ei leitud (Norbury, Bishop 2003).

\section{Narratiivi analüüs kõnearengu hindamise meetodina}

Kuigi alakõnega ja eakohase kõnearenguga laste narratiive võrdlevate uurimuste hulk on viimastel aastatel tõusnud, puudub siiani üksmeel sobivaima meetodi osas AK diagnoosimisel. Donna Merritt ja Betty Liles (1989) soovitavad narratiivi makrostruktuuri hindamisel kasutada vahendatud jutustust, mille analüüs võimaldab jõuda usaldusväärsemate tulemusteni, võrreldes vahendamata jutustusega. 
Lisaks on leitud, et erinevused EK ja AK laste rühmade vahel on oluliselt suuremad just vahendatud narratiivides (Merritt, Liles 1987, 1989). Samas eelistavad Schneider jt (2006) jutustamisoskuse hindamisel kasutada just vahendamata jutustust, mis peegeldab paremini sõltumatuid tekstiloomeoskusi, kuna tuleb planeerida ja formuleerida täiesti iseseisvalt. Analüüsitulemuste usaldusväärsuse tagamiseks soovitavad autorid kasutada pildiseeria alusel jutustamist.

Vahendamata jutustusi käsitlevates uurimustes on narratiive koostatud kahel viisil - ilma eelneva verbaalse näidise ehk mudelita (nt Liles 1987, Merritt, Liles 1987, 1989, Scott, Windsor 2000, Norbury, Bishop 2003, Pearce jt 2003, Reilly jt 2004) ning eelneva narratiivi mudeliga (näidisjutu esitamine, treeningjutu ühine koostamine enne testimist vm) (nt Reuterskiöld Wagner jt 1999, Fey jt 2004, Schneider jt 2006). Meile teadaolevalt ei ole aga nimetatud narratiivi tüüpe võrdlevaid uurimusi erineva kõnearenguga lasterühmades läbi viidud. Seega puudub senini üksmeel, missugust jutustamisviisi (vahendatud $v s$. vahendamata narratiiv, eelneva narratiivi mudeliga $v s$. eelneva mudelita jutustamine) eelistada laste jutustamisoskuste uurimises ning alakõne diagnostikas.

\section{Eakohase kõnearenguga ja alakõnega eesti laste narratiivid: eesmärk ja hüpoteesid}

Eesti laste jutustamisoskusi on viimastel aastatel uuritud vaid üliõpilastööde raames (nt Pajuste 2007, Adamka 2008, Ruul 2009) ning esialgu puudub terviklik ülevaade laste, sh AK laste oskustest. Seda oleks aga vaja laste kõnearengu hindamisel ning toetamisel. Uurimuses võrdleme 6-7-aastaste EK ja AK eesti laste narratiive, mis on koostatud kolmel viisil: vahendamata jutustus ilma eelneva narratiivi mudelita, vahendatud jutustus, vahendamata jutustus eelneva narratiivi mudeliga. Uurimuse teoreetiline olulisus seisneb AK laste tekstiloomeraskuste ja eri jutustamisviiside seostamises. Praktiline eesmärk on kirjeldada 6-7 aasta vanuste eesti laste jutustamisoskusi narratiivi mikro- ja makrostruktuuri tasandil ning selgitada, mil viisil jutustatud narratiivid eristavad alakõnet eakohasest arengust kõige paremini. Eesmärgist tulenevalt on püstitatud kolm hüpoteesi.

1. Võttes aluseks eelnevad uurimused, mis käsitlevad AKja EK laste narratiivide mikrostruktuuri (nt Liles jt 1995, Reuterskiöld Wagner jt 1999, Scott, Windsor 2000, Botting 2002, Norbury, Bishop 2003, Pearce jt 2003, Fey jt 2004, Reilly jt 2004, Bishop, Donlan 2005, Peña jt 2006, Hayward jt 2007) ja makrostruktuuri (nt Reutersköld Wagner jt 1999, Schneider jt 2006), ning AK kolmanda tasandi diagnostilised kriteeriumid - primitiivne tekst ja lause (vt allmärkus nr 2), eeldasime, et kõigil kolmel viisil koostatud narratiivid on AK korral EK lastega võrreldes mikro- ja makrostruktuuri osas madalamal tasemel.

2. Teksti ümber jutustades, erinevalt iseseisvast tekstiloomest, ei väljenda kõneleja oma mõtet, vaid vahendab varem tajutud teksti. Selleks tuleb aga seda mõtestada ja mäletada. Teksti mõistmine, mis sõltub tajuja kognitiivsest arengust ja keelelistest oskustest, on AK korral eakohasest tasemest maha jäänud (vt Leonard 1998: 86). Mitmetes uuringutes on leidnud kinnitust ka AK laste mäluprotsesside eakohasest madalam arengutase 
(vt Vance 2008). Toetudes teadmistele AK laste kognitiivsest ja keelelisest arengust, samuti vahendamata ja vahendatud jutustusi võrdlevate uuringute tulemustele (Merritt, Liles 1987, 1989), eeldasime, et vahendatud narratiivid eristavad EK ja AK laste rühmi paremini kui vahendamata narratiivid. Nimelt oletasime, et teksti reprodutseerimisel on EK lapsed AK lastest oluliselt edukamad teksti sisulisel ja keelelisel koostamisel ning erinevused jutustamisoskustes ilmnevad kõige selgemini just vahendatud narratiivides.

3. Eesmärgiga tutvustada lapsele jutu formaati, soovitavad Schneider jt (2006) enne oskuse hindamist viia läbi harjutusjutt mingil muul teemal ehk kasutada mudeldamist. On leitud, et kuigi mudeldamisest on kasu nii eakohase kui mahajäänud kõnearenguga lastel, õpivad sellest enam EK lapsed ning mudeldamise mõju on oluliselt väiksem AK korral (Peña jt 2006). Käesolevas töös eeldasime, et vahendamata jutustus, millele eelnes näidisjutt, eristab EK ja AK laste rühmi paremini kui eelnevalt mudeldamata vahendamata jutustus ning mudeldamisel on positiivne mõju eelkõige EK laste tekstiloomele narratiivi makrostruktuuri tasandil.

\section{Meetod}

\subsection{Valim}

Uuringus osales 189 eesti keelt emakeelena kõnelevat 6-7-aastast last, kellest 162 oli eakohaselt arenenud kõnega ning 27 alakõnega. EK lapsed käisid lasteaia koolieelsetes rühmades (6 maakonnast, 21 lasteaiast), lapsi testiti õppeaasta lõpus kevadel. EK rühma loeti lapsed, kelle kõnearengu taset pidasid lasteaiaõpetajad keskmiseks või kõrgeks (küsitletud ankeedis), madalaks hinnatud kõnearengu tasemega lapsed jäeti valimist välja. AK lapsed käisid kõnepuuetega laste erikoolis, testimine toimus 1. klassi alguses sügisel. Kõik AK lapsed olid kooli suunatud rahvusvahelise haiguste klassifikatsiooni (RHK-10 1993) kliinilise diagnoosi alusel: 13 lapsel esines ekspressiivne kõnehäire (F80.1), 7 lapsel retseptiivne kõnehäire (F80.2), 7 lapsel segatüüpi spetsiifilised arenguhäired (F83) ${ }^{3}$, kõikidel lastel oli logopeed diagnoosinud alakõne (kolmas tasand). EK rühmas oli 72 (44\%) poissi ja 90 (56\%) tüdrukut, AK rühmas 16 (59\%) poissi ja 11 (41\%) tüdrukut. Enne uuringu läbiviimist paluti laste testimiseks lapsevanematelt kirjalikus vormis luba ning valimisse võeti vaid lapsed, kelle vanemad olid andnud selleks nõusoleku.

\subsection{Vahendid}

Jutustamisel kasutati kolme viieosalist pildiseeriat (kelgulugu, pallilugu, lumememmelugu) ning kahte teksti (pallilugu, lumememmelugu). ${ }^{4}$ Pildiseeriatel kujutatud keskkond, tegelased ja tegevused olid eeldatavalt lastele tuttavad ning arusaadavad.

\footnotetext{
3 F80.1 korral on lapse väljendusoskus märkimisväärselt madalam ealisest normtasemest, kõnest arusaamine on seejuures normi piires. F80.2 korral on lapse arusaamine keelelistest konstruktsioonidest puudulikum tema eale vastavast tasemest, ekspressiivne kõne on enamasti puudulik (RHK-10 1993: 223-226). F83 on "raskesti defineeritav, ebapiisava täpsusega määratletud häirete kategooria, mille puhul spetsiifilised keele-/kõne-, õpivilumuste ja/või motoorsete funktsioonide häired on segunenud" (RHK-10 1993: 239). Kõikidele nimetatud puuetele on iseloomulik alakõne ning mõningane kognitiivsete funktsioonide kahjustus, vaimse arengu tase on siiski eanormi piires. 4 Narratiivide süžee ning tekstid koostasid Merit Hallap, Marika Padrik, Piret Soodla ja Kati Sütt, pildid joonistas Jolana Laidma. Piltide ja tekstide näidiseid vt Pajuste (2007) ja Adamka (2008).
} 
Narratiivide usaldusväärse kodeerimise eesmärgil püüti pildiseeriad ja tekstid koostada keeleliselt ja sisuliselt sarnase raskusastme ning struktuuriga. Pildiseeriatel kujutatu vastas jutugrammatika mudelile (Stein, Glenn 1979), osutades mudeli sisukomponentidele (taust, käivitav sündmus, sisemine vastus, sisemine plaan, tegevus, tagajärg, reaktsioon). Pildiseeriatele vastavad tekstid sisaldasid samuti kõiki jutugrammatika komponente, tekstid olid sarnase pikkuse (palliloos 136, lumememmeloos 145 sõna), grammatilise ehituse (lausungite keskmine pikkus mõlemas jutustuses 6 sõna), infoüksuste hulga (palliloos 20, lumememmeloos 21 infoüksust) ning komplekssusega (palliloos 20, lumememmeloos 21 punkti). Lausungite, infoüksuste hulga ja narratiivi komplekssuse käsitlusi vt allosas 6.4.

\subsection{Protseduur}

Testimine viidi läbi individuaalselt. Iga laps jutustas kolm narratiivi, mis lindistati ning hiljem transkribeeriti. Esimese jutustuse aluseks oli kelguloo pildiseeria, teise ja kolmanda jutu aluseks olevaid seeriaid vahetati iga järgneva lapse korral: 98 last jutustasid teisena palliloo ja kolmandana lumememmeloo, 91 juhul oli pildiseeriate järjekord vastupidine.

1. Vahendamata narratiiv eelneva mudelita (edaspidi 1. narratiiv). Testi läbiviija asetas lapse ette lauale kelguloo seeria esimese pildi ning palus ülejäänud pildid järjestada nii, et neist tekiks jutuke. Kui laps järjestas pildid valesti, pani testija need ise õigesse järjekorda. Lapsele anti piltide vaatamiseks aega ning paluti jutustada nende järgi üks lugu.

2. Vahendatud narratiiv (2. narratiiv). Testija asetas ükshaaval lapse ette pilte ning paralleelselt luges ette piltide kohta käiva jutukese (palli- või lumememmeloo). Peale jutu kuulamist paluti lapsel lugu ümber jutustada.

3. Vahendamata narratiiv eelneva mudeliga (3. narratiiv). Testimise protseduur oli sarnane 1. narratiivile. Lapsed jutustasid lumememme- või palliloo (vastavalt sellele, kumba nad 2. narratiivina ei jutustanud). Narratiivi mudeliks oli 2. narratiivi aluseks olnud originaaltekst.

\subsection{Narratiivide kodeerimine}

Analüüs hõlmas narratiivide mikrostruktuuri - lausungite keskmist pikkust ja grammatilist õigust, ning makrostruktuuri - infoüksuste hulka ja komplekssust.

1. Lausungite keskmine pikkus (LP) on tekstis esinenud sõnade hulga ja lausungite hulga suhe. Lausungiteks peeti järgmisi süntaktilisi üksusi: 1) lihtlaused, 2) pealaused koos sellele alistuvate kõrvallausetega, 3) elliptilised lausungid, 4) väljendid, milles on puudu obligatoorsed lauseliikmed, kuid mis on eelnevast või järgnevast lausungist pauside abil eraldatud. Rinnastusseoses olevaid osalaused loeti eraldi lausungiteks. Lausungiteks jaotamisel lähtuti Diana Hughes’i jt (1997: 53) soovitustest, mõiste vastab ingliskeelsele terminile communication unit.

2. Grammatikavigade sagedus (GVS) on jutus esinenud vigade ja sõnade koguhulga suhe. Grammatikavigadeks loeti järgmisi eksimusi. 
2.1. Süntaksivead: sõnajärjevead (oli ilm ilus kevad), obligatoorse lauseliikme puudumine (Lili ei suutnud Martinit___), sidendivead (Anna kartis selleks et vesi oli sügav) ja sisulisse konteksti sobimatu sõnavorm (see tüdruk sõidaks alla ja sõidaks (pro sõitis) vastu puud).

2.2. Morfoloogiavead: süntaktilisse konteksti sobimatud sõnavormid, s.t vale morfoloogiline vorm (nad hakkasid juba ülesse minna) või sõnavormi moonutamine (nad veeretasi. siis tõstsi.). Morfoloogiavigade hulka lugesime ka morfofonoloogilised vead (tooda pro tuua).

Grammatikavigade hulka ei loetud 1) suulisele kõnele iseloomulikke nähtusi - katkestusi, kordusi, parandusi, lihtsustunud sõnavorme (ehmund pro ehmunud), sõnaalgulise $h$-i puudumist, 2) hääldusvigu (tügruk pro tüdruk), 3) leksikaalseid vigu (solvunud pro kurb) ning 4) pragmaatilisi vigu (nt eksimused sündmuste järjestamisel, arusaamatu sisu vm).

3. Infoüksuste hulk (IÜH) on olulise informatsiooni hulk narratiivis. Kodeerimisel võeti aluseks jutugrammatika mudel (Stein, Glenn 1979), s.t analüüsiti jutugrammatika komponentides sisalduvate infoüksuste hulka (Hayward, Schneider 2000 järgi). Näiteks taustakirjelduse osas arvestati punkte tegelaste, tegevuse aja ja koha ning muu olulise taustainformatsiooni nimetamise eest, tegevuse kategooria osas anti punkte tegelaste eesmärgipäraste üksiktoimingute eest jne. Sisult samade väidete eest anti vaid üks punkt. Lõpuks liideti saadud punktid kokku ning analüüsis kasutati jutugrammatika komponentides sisalduvate infoüksuste koguhulka. Kodeerimisjuhis vt Adamka (2008).

4. Narratiivi komplekssuse indeks (NKI) sisaldab järgmisi kategooriaid: tegelased, taustakirjeldus, käivitav sündmus, sisemised vastused, plaanid, tegevused, takistused, tagajärjed, dialoog, jutustajapoolsed hinnangud, jutu algust ja lõppu tähistavad vormelmarkerid ning aja- ja põhjusseoseid väljendavad keelendid (Petersen jt 2008 järgi). Lisaks nimetatud kategooriates sisalduva informatsiooni hulgale võetakse arvesse ka elementidevahelisi seoseid. Kodeerimisjuhis vt lisa 1.

\subsection{Kodeerimise usaldusväärsus}

Analüüsitulemuste usaldusväärsuse eesmärgil kodeeris 50 (27\%) lapse tekstid mitu kodeerijat. Grammatikavigade osas oli hindajatevaheline usaldusväärsus (väljendatud Spearmani korrelatsioonikordaja $R$ abil) 1., 2. ja 3. narratiivis vastavalt 0,57 , 0,61 ja 0,57 . Arvestades suulise keele suhteliselt lõtva struktureeritust ja väiksemat allumist mitmesugustele normingutele (võrreldes kirjaliku keelega), võib usaldusväärsust vigade osas hinnata rahuldavaks. IÜH ja NKI osas olid kodeeringute kokkulangevused kõigis kolmes narratiivis head: Spearmani $R$ oli vastavalt 0,85 , o,86 ja 0,84 (IÜH); o,81, o,88 ja 0,83 (NKI). 


\subsection{Statistilised analüüsid}

Andmeanalüüsil kasutasime järgmisi statistilise analüüsi meetodeid: eri pildiseeriate alusel jutustatud narratiivide (2. ja 3. narratiivi) struktuurinäitajate (LP, GVS, IÜH, NKI) keskmiste väärtuste võrdlemisel t-testi, EK ja AK rühmade narratiivide struktuurinäitajate keskmiste väärtuste võrdlemisel korduvmõõtmistega dispersioonanalüüsi ANOVA, mille post hoc testina (erinevuste mustri väljatoomiseks) kasutasime Bonferroni testi. Tunnuste mõju suuruse hindamisel olid kasutusel Cohen'i $d$ (t-testi ja Bonferroni testi korral) ja osaline eta ruut $\eta_{p}{ }^{2}$ (ANOVA korral). Statistiliste testide puhul oli olulisuse nivoo $\alpha=0,05$. Mõju suurust hindasime väikeseks $\left(d \geq 0,2, \eta_{p}{ }^{2}<0,06\right)$, keskmiseks $\left(d \geq 0,5, \eta_{p}{ }^{2}<0,14\right)$ või suureks $(d \geq 0,8$, $\left.\eta_{p}{ }^{2} \geq 0,14\right)$ (Vacha-Haase, Thompson 2004, Cohen jt 2007).

\section{Tulemused}

\subsection{Pildiseeriate võrdlused}

Eesmärgiga selgitada, kas kahe pildiseeria (palli- ja lumememmeseeria) alusel laste poolt koostatud narratiivid on analüüsitavate tunnuste osas sarnased ehk kas vastavaid narratiive saaks analüüsida koos, võrdlesime eri seeriate alusel koostatud EK laste jutustuste struktuurinäitajate keskmisi väärtusi (LP, GVS, IÜH, NKI) t-testi abil. LP, GVS ja IÜH osas palli- ja lumememmeseeria alusel koostatud narratiivide vahel statistiliselt olulisi erinevusi ei esinenud (nii 2. kui ka 3. narratiivis LP, GVS ja IÜH osas $p>0,05$ ), erinevused ilmnesid vaid NKI-s (2. narratiiv: $t(160)=2,48$, $p=0,014, d=0,39 ; 3$. narratiiv: $t(160)=1,98, p=0,049, d=0,32)$.

Kuna LP, GVS ja IÜH poolest palli- ja lumememmejutud ei erinenud, analüüsisime eri seeriate alusel koostatud narratiive nende kategooriate osas edaspidi koos. NKI analüüsid viisime palli- ja lumememmeseeria järgi koostatud narratiivides läbi eraldi. Narratiivide struktuurinäitajate andmed EK ja AK rühmades on esitatud tabelis 1.

Tabel 1. Lausungite keskmine pikkus, grammatikavigade sagedus, infoüksuste hulk ja narratiivi komplekssuse indeks eakohase kõnearenguga ja alakõnega laste narratiivides: aritmeetilised keskmised ja standardhälbed (sulgudes)

\begin{tabular}{|l|c|c|c|c|c|c|}
\hline \multirow{2}{*}{$\begin{array}{l}\text { Narratiivide } \\
\text { struktuurinäitajad }\end{array}$} & \multicolumn{2}{|c|}{ 1. narratiiv } & \multicolumn{2}{c|}{ 2. narratiiv } & \multicolumn{2}{c|}{ 3. narratiiv } \\
\cline { 2 - 7 } Lausungite keskmine & EK & AK & EK & AK & EK & AK \\
pikkus & 6,40 & 5,09 & 6,56 & 4,66 & 6,11 & 4,85 \\
\hline Grammatikavigade & $(1,59)$ & $(1,33)$ & $(1,15)$ & $(1,03)$ & $(1,26)$ & $(1,16)$ \\
sagedus & 0,04 & 0,14 & 0,03 & 0,10 & 0,03 & 0,10 \\
\hline \multirow{2}{*}{ Infoüksuste hulk } & $(0,04)$ & $(0,11)$ & $(0,03)$ & $(0,08)$ & $(0,03)$ & $(0,07)$ \\
\hline Narratiivi komplekssuse & 7,04 & 5,70 & 10,04 & 6,85 & 7,88 & 6,07 \\
indeks (rühm A) & $(1,87)$ & $(1,07)$ & $(2,31)$ & $(2,14)$ & $(1,95)$ & $(1,69)$ \\
\hline Narratiivi komplekssuse & 7,81 & 6,17 & 14,09 & 9,50 & 9,98 & 6,25 \\
indeks (rühm B) & $(2,15)$ & $(1,47)$ & $(2,73)$ & $(2,65)$ & $(3,06)$ & $(0,75)$ \\
\hline
\end{tabular}




\subsection{Lausungite keskmine pikkus}

EK lapsed koostasid jutustamisel lausungeid, mille sõnade arv ületas keskmiselt kuus sõna, AK lastel jäi LP viie sõna piiresse (vt joonis 1). Dispersioonanalüüsi tulemustest selgub, et kõnearengu taseme mõju oli statistiliselt oluline $(F(1,187)=56,12$, $\left.p<0,001, \eta_{p}{ }^{2}=0,23\right)$, post hoc test näitas, et EK ja AK lastel erines LP kõikides jutustustes (1. narratiiv: $p=0,003, d=0,90 ; 2$. narratiiv: $p<0,001, d=1,74 ; 3$. narratiiv: $p=0,005, d=1,04)$. Statistiliselt oluliseks ei osutunud jutustamisviisi mõju $\left(F(2,374)=1,23, p>0,05, \eta_{p}{ }^{2}=0,01\right)$ ega kõnearengu taseme ja jutustamisviisi koosmõju $\left(F(2,374)=2,26, p>0,05, \eta_{p}{ }^{2}=0,01\right)$. Seega, LP oli AK rühma narratiivides oluliselt väiksem võrreldes EK lastega ning jutustamisviis LP-le kummaski rühmas mõju ei avaldanud.

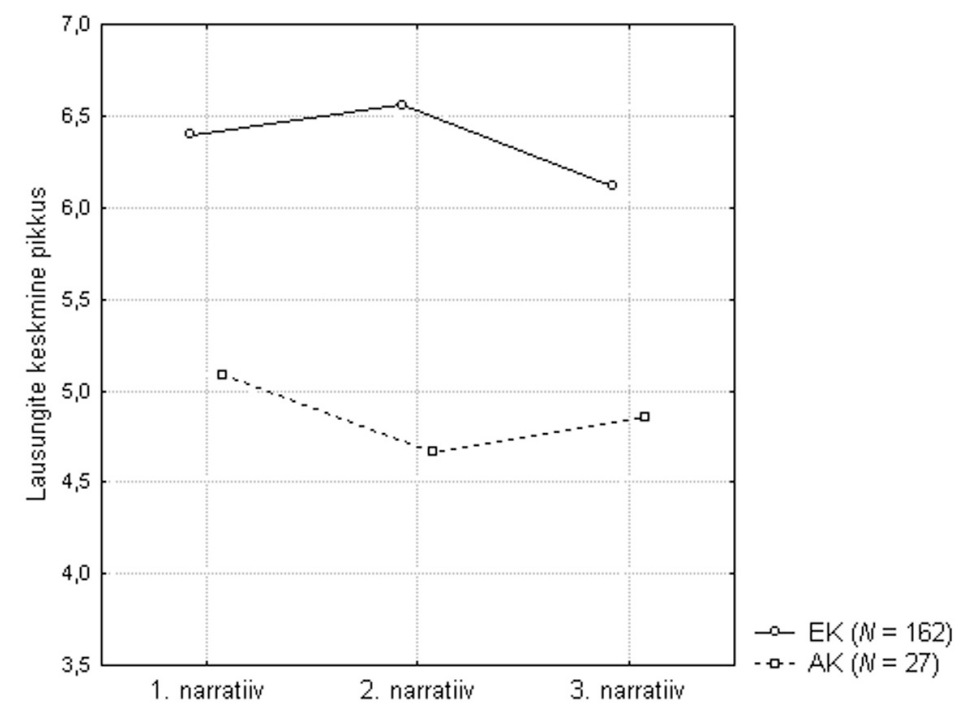

Joonis 1. Lausungite keskmine pikkus sõnades eakohase (EK) ja alakõnega (AK) laste narratiivides

\subsection{Grammatikavigade sagedus}

GVS erines lasterühmade ja eri viisil jutustatud narratiivide vahel mitmes mõttes (vt joonis 2). Statistiliselt oluline oli nii kõnearengu taseme mõju $(F(1,187)=123,98$, $\left.p<0,001, \eta_{p}{ }^{2}=0,40\right)$, jutustamisviisi mõju $\left(F(2,374)=11,70, p<0,001, \eta_{p}{ }^{2}=0,06\right)$ kui ka kõnearengu taseme ja jutustamisviisi koosmõju $(F(2,374)=4,62, p=0,011$, $\left.\eta_{p}{ }^{2}=0,02\right)$. Post hoc test näitas, et GVS oli kõikides narratiivides AK rühmas suurem kui EK lastel ( $p<0,001, d>0,8)$. EK rühmas vigade sagedus kolme narratiivi lõikes ei muutunud ( $p>0,05, d<0,28$ ), küll aga erines AK lastel vigade hulk 1. ja 2. narratiivi $(p=0,007, d=0,38)$ ning 1. ja 3. narratiivi vahel $(p=0,002, d=0,42)$.

Grammatikavigade liike analüüsisime vähendatud valimis, kaasates analüüsi 44 juhuslikult valitud EK lapse jutud ning kõigi 27 AK lapse jutud. Mõlemas rühmas olid ülekaalus süntaksivead (EK 64\%, AK 69\%), morfoloogiavead moodustasid umbes kolmandiku vigadest (EK 36\%, AK 31\%).

Tulemused näitasid seega, et GVS oli AK rühmas EK lastega võrreldes kõikides narratiivides oluliselt suurem, vigade jaotumine rühmades oli sarnane. AK rühmas langes GVS 2. ja 3. narratiivis oluliselt võrreldes 1. narratiiviga. 


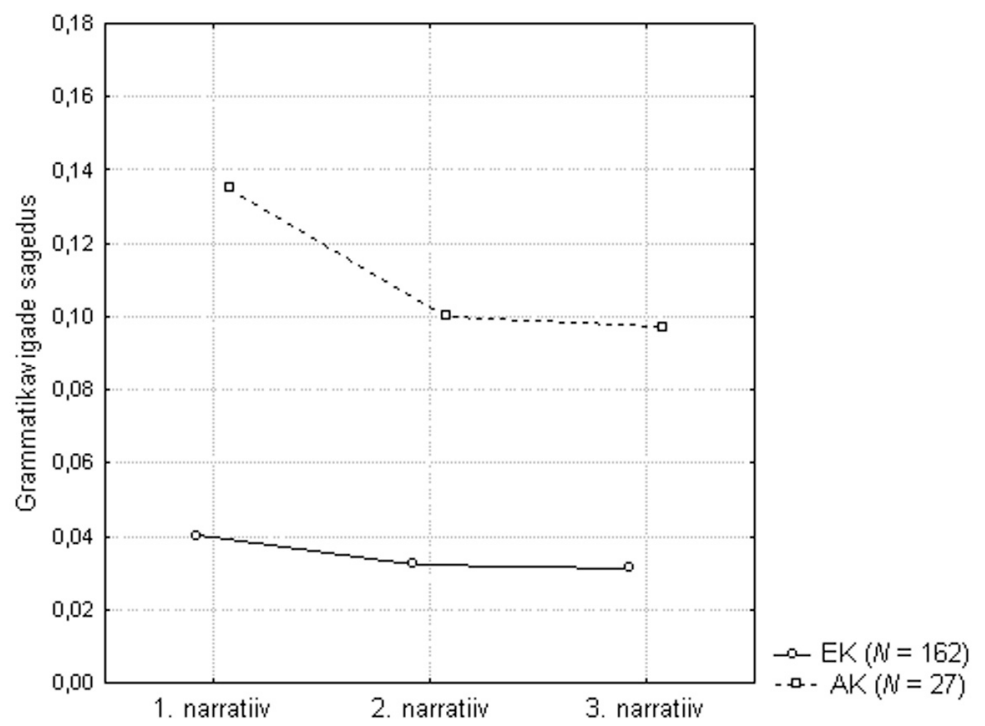

Joonis 2. Grammatikavigade sagedus eakohase (EK) ja alakõnega (AK) laste narratiivides

\subsection{Infoüksuste hulk}

IÜH osas ilmnes statistiliselt oluline kõnearengu taseme mõju $(F(1,187)=44,34$, $\left.p<0,001, \eta_{p}{ }^{2}=0,19\right)$, jutustamisviisi mõju $\left(F(2,374)=41,48, p<0,001, \eta_{p}{ }^{2}=0,18\right)$ ning kõnearengu taseme ja jutustamisviisi koosmõju $(F(2,374)=8,48, p<0,001$, $\left.\eta_{p}{ }^{2}=0,04\right)$. Post hoc test osutas EK ja AK laste narratiivide IÜH olulistele erinevustele 2. ja 3. narratiivis (vastavalt $p<0,001, d=1,43$ ja $p=0,018, d=0,99$ ), 1. narratiivi puhul ei ületanud erinevus olulisuse nivood ( $p>0,05, d=0,88)$. Jutustuste lõikes selgus, et EK lastel tõusis IÜH (1. narratiiviga võrreldes) oluliselt nii 2. kui ka 3. narratiivis (vastavalt $p<0,001, d=1,43 ; p<0,001, d=0,44$ ). Ka AK rühmas tõusis IÜH 2. ja 3. narratiivis, kuid mitte statistiliselt olulisel määral (vastavalt $p>0,05, d=0,68$ ja $p>0,05, d=0,26$ ).

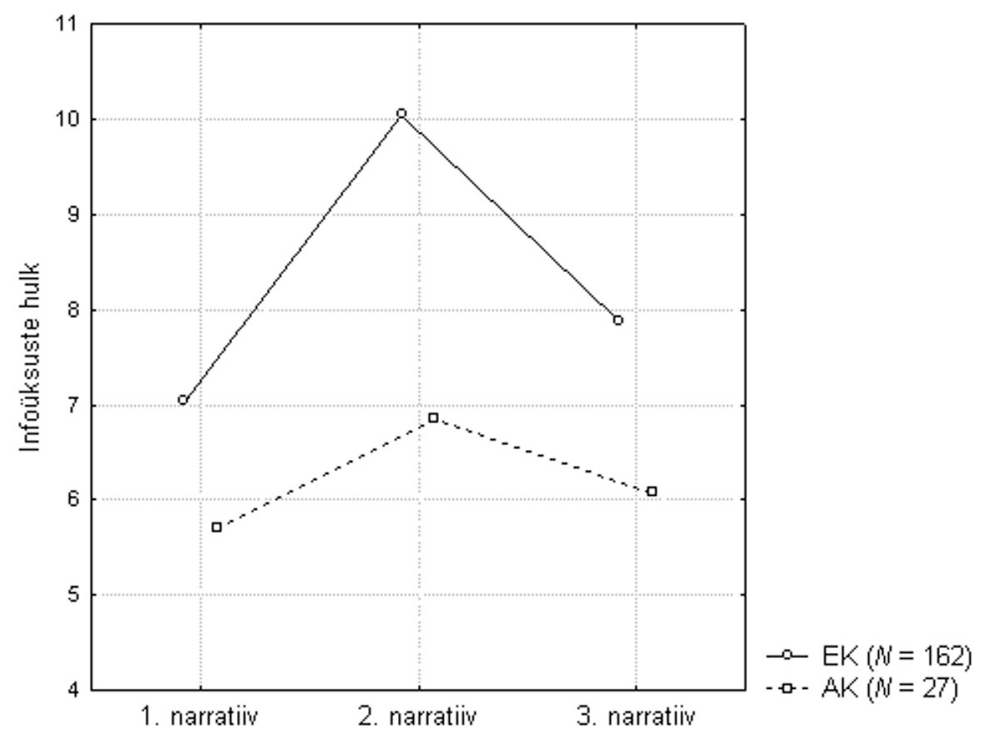

Joonis 3. Infoüksuste hulk eakohase (EK) ja alakõnega (AK) laste narratiivides 
Analüüs näitas seega, et IÜH oli 2. ja 3. narratiivis AK rühmas oluliselt väiksem kui EK lastel ning jutustamisviisi statistiliselt oluline mõju ilmnes vaid EK laste puhul, kelle 2. ja 3. narratiivid olid 1. jutustusega võrreldes oluliselt inforikkamad.

\subsection{Narratiivi komplekssuse indeks}

NKI osas viisime analüüsid läbi kahes rühmas: rühma A moodustasid lapsed, kes jutustasid teisena pallilugu ja kolmandana lumememmelugu $(N=98)$, rühmas B oli 2. ja 3. narratiivi aluseks olevate seeriate järjekord vastupidine $(N=91)$. Dispersioonanalüüsi tulemusel selgus, et statistiliselt oluline oli kõnearengu taseme mõju (rühmas A: $F(1,96)=30,13, p<0,001, \eta_{p}{ }^{2}=0,24$; rühmas $\mathrm{B}: F(1,89)=13,93$, $\left.p<0,001, \eta_{p}{ }^{2}=0,14\right)$ ning jutustamisviisi mõju $(\mathrm{A}: F(2,192)=62,97, p<0,001$, $\left.\eta_{p}{ }^{2}=0,40 ; \mathrm{B}: F(2,178)=48,34, p<0,001, \eta_{p}{ }^{2}=0,35\right)$. Kõnearengu taseme ja jutustamisviisi koosmõju oli oluline rühmas $\mathrm{A}\left(F(2,192)=5,71, p=0,004, \eta_{p}{ }^{2}=0,06\right)$, rühmas B ilmnes nõrk koosmõju tendents, jäädes siiski statistiliselt mitteoluliseks $\left(F(2,178)=2,39, p=0,095, \eta_{p}{ }^{2}=0,03\right)$.

Rühmas A erines NKI EK ja AK laste vahel statistiliselt olulisel määral 2. ja 3. narratiivis (vastavalt $p<0,001, d=1,71$ ja $p=0,009, d=1,67$ ), 1 . narratiivis ei osutunud erinevused oluliseks ( $p>0,05, d=0,90$ ). Rühmas B erines NKI EK ja AK laste vahel oluliselt vaid 2. narratiivis $(p=0,021, d=1,01), 1$. ja 3. narratiivi puhul ei olnud erinevused statistiliselt olulised (vastavalt $p>0,05, d=0,63$ ja $p>0,05, d=0,83$ ).

Kolme narratiivi võrdlusel selgus, et EK lastel tõusis NKI oluliselt (1. narratiiviga võrreldes) nii 2. narratiivis (A: $p<0,001, d=2,56$; $\mathrm{B}: p<0,001, d=1,75$ ) kui ka 3. narratiivis (A: $p<0,001, d=0,82$; B: $p<0,001, d=1,29)$. AK lastel oli NKI 2. narratiivis samuti oluliselt kõrgem kui 1. narratiivis (A: $p=0,002, d=1,56$; $\mathrm{B}$ : $p<0,001, d=1,45), 3$. narratiivis olid A ja B rühmas tulemused erinevad, osutudes oluliseks vaid rühmas $\mathrm{B}$ (A: $p>0,05, d=0,07$; $\mathrm{B}: p=0,023, d=1,43$ ).

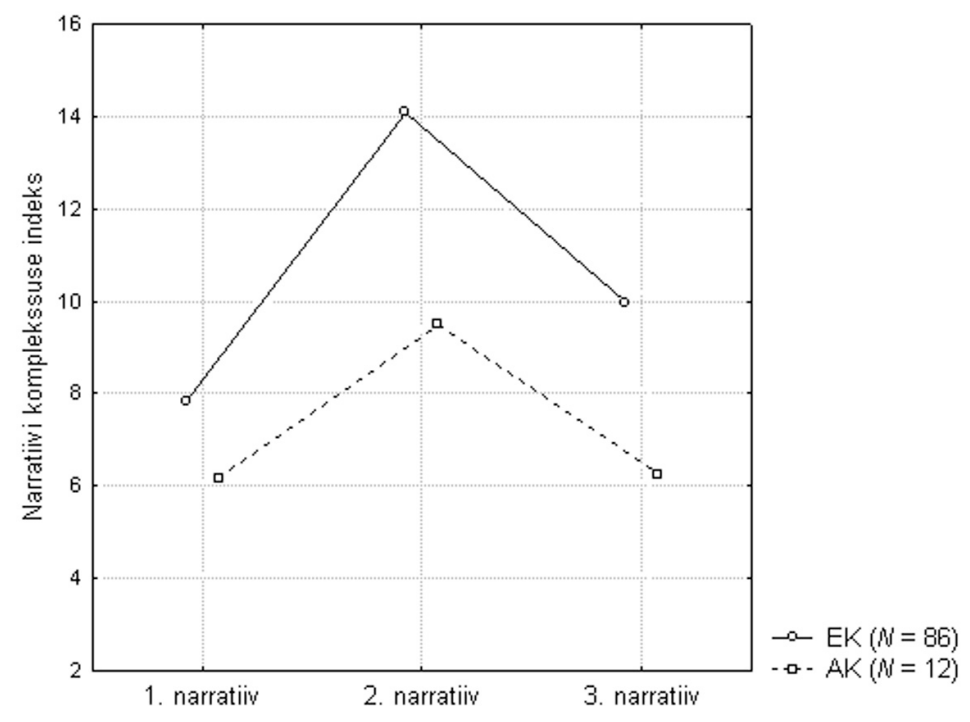

Joonis 4. Narratiivi komplekssuse indeks eakohase (EK) ja alakõnega (AK) laste narratiivides (rühm A) 


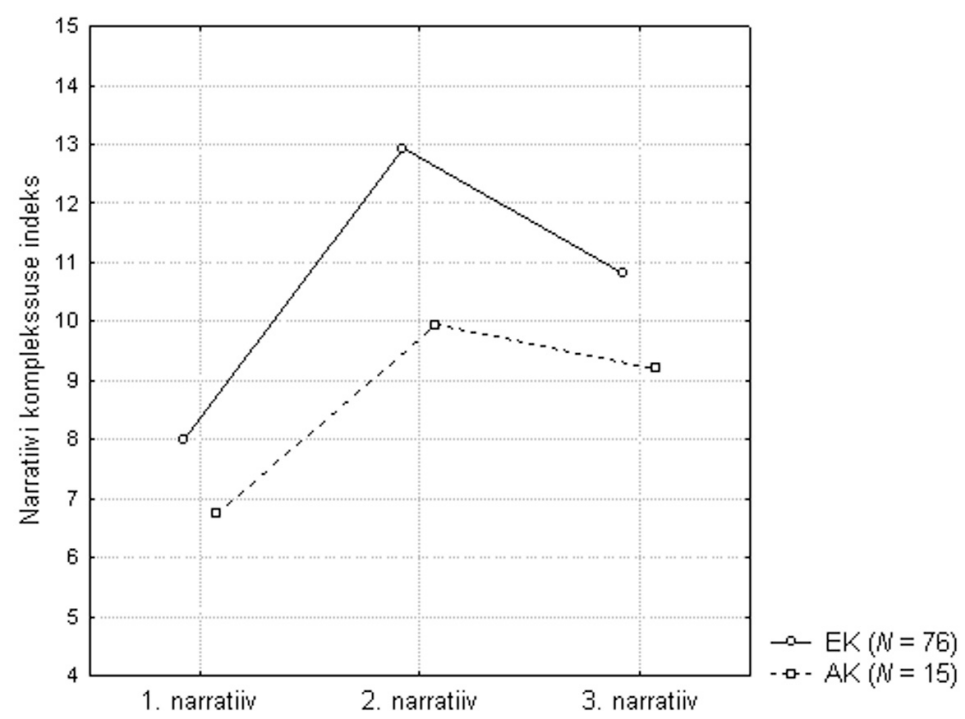

Joonis 5. Narratiivi komplekssuse indeks eakohase (EK) ja alakõnega (AK) laste narratiivides (rühm B)

Analüüs näitas seega, et NKI oli AK lastel EK lastega võrreldes oluliselt madalam 2. narratiivis (nii A kui B rühmas) ja 3. narratiivis (rühmas A). 1. narratiivis ei erinenud NKI EK ja AK rühmade vahel statistiliselt olulisel määral. Jutustamisviisi mõju ilmnes selgelt vaid EK lastel, kelle 2. ja 3. narratiivi NKI oli 1. narratiiviga võrreldes oluliselt suurem.

\section{Arutelu ja kokkuvõte}

Vaatluse all olid 6-7 aasta vanuste eakohase kõnearenguga ja alakõnega eesti laste suulised narratiivid: vahendamata jutustused ilma eelneva narratiivi mudelita, vahendatud jutustused ning vahendamata jutustused eelneva narratiivi mudeliga. Analüüsisime nimetatud kolmel viisil jutustatud narratiivide mikrostruktuuri - lausungite keskmist pikkust ja grammatikavigu, ning makrostruktuuri - jutugrammatika mudelil (Stein, Glenn 1979) põhineva olulise informatsiooni hulka ja narratiivi komplekssust, mis hõlmab jutustuse episoodilist struktuuri, jutustajapoolseid hinnanguid ning lausungeid siduvaid keelendeid (Petersen jt 2008 järgi).

Eeldasime, et kõigil kolmel viisil jutustatud narratiivid on AK lastel EK lastega võrreldes madalamal tasemel kõikide analüüsitavate näitajate osas. Hüpotees leidis kinnitust narratiivi mikrostruktuuri osas: AK laste LP oli oluliselt väiksem ning GV sagedus oluliselt kõrgem, võrreldes EK laste narratiividega. Tulemused on kooskõlas inglise keelel põhinevate uurimistulemustega lausungipikkuse (Scott, Windsor 2000, Bishop, Donlan 2005, Hayward jt 2007) ning grammatilise õigsuse kohta (Scott, Windsor 2000, Norbury, Bishop 2003, Pearce jt 2003, Fey jt 2004). Makrostruktuuri näitajate osas ilmnes samuti kõnearengu taseme mõju, mis siiski ei osutunud kõikide narratiivide osas statistiliselt oluliseks. Nimelt sisaldasid EK laste jutustused AK laste narratiividega võrreldes oluliselt rohkem infoüksusi vaid vahendatud narratiivis ja eelnevalt mudeldatud vahendamata narratiivis, eelnevalt mudeldamata vahendamata narratiivide IÜH erinevus ei olnud statistiliselt oluline. Ka narratiivi komplekssuse osas leidis hüpotees kinnitust vaid osaliselt, 
s.t vahendatud narratiivide osas, mille NKI oli AK lastel oluliselt väiksem kui EK lastel. Eelnevalt mudeldamata narratiivide NKI ei olnud lasterühmade vahel oluliselt erinev, eelnevalt mudeldatud vahendamata narratiivide NKI erines oluliselt vaid rühmas A. Tulemused näitavad seega, et narratiivide mikrostruktuur (LP ja GVS) oli AK lastel EK lastega võrreldes oluliselt madalamal tasemel kõigil kolmel viisil jutustatud narratiivides. Narratiivide makrostruktuur (IÜH ja NKI) oli AK lastel oluliselt madalamal tasemel vahendatud jutustustes ning eelnevalt mudeldatud vahendamata jutustustes (osaliselt). Seega võib saadud tulemuste põhjal nõustuda Betty Lilesi jt (1995) ning Cheryl Scotti ja Jennifer Windsori (2000) väitega, et just lausetasandi näitajad eristavad hästi esmase alakõnega lapsi EK lastest, kuigi ka narratiivide makrostruktuur on AK korral eakohaselt arenenud lastega võrreldes primitiivsem.

Teise hüpoteesina eeldasime, et vahendatud narratiivid eristavad EK ja AK rühmi vahendamata jutustustest paremini. Mikrostruktuuri näitajate osas ei leidnud hüpotees kinnitust. Nimelt olid muutused LP osas kolme jutustuse lõikes väiksed ning ei osutunud statistiliselt oluliseks mitte kummaski lasterühmas. Grammatikavigade osas selgus, et EK rühmas oli GVS kolme narratiivi lõikes stabiilselt madal, AK rühmas oli see aga vahendatud ja eelnevalt mudeldatud vahendamata jutustuses oluliselt madalam, võrreldes eelnevalt mudeldamata jutustusega. Vigade vähenemine $\mathrm{AK}$ rühmas võib olla seletatav võimalusega, et 1. narratiivi puhul ei olnud AK lastele jutustamise ülesanne piisavalt arusaadav, mistõttu lapsed ei olnud motiveeritud koostama keeleliselt korrektset jutukest. Vahendatud jutustuse aluseks olev originaaltekst toimis lastele tõenäoliselt keelelise mudelina nii 2. kui 3. jutustuse koostamisel. Lisaks võib oletada, et vahendatud jutustuses reprodutseerisid AK lapsed osaliselt originaaltekstis esinenud grammatilisi vorme, mis tingis ka vigade vähenemise. Vigade langustrendi puudumine EK laste rühmas on seletatav niigi madala vigade hulgaga juba 1. narratiivis. Makrostruktuuri näitajate osas leidis hüpotees kinnitust: nii IÜH kui ka NKI erinevused olid EK ja AK rühmade vahel suurimad vahendatud jutustustes, näidates, et EK lastel tõusis vahendatud narratiivis informatsiooni hulk ja komplekssus AK lastega võrreldes oluliselt enam. Saadud tulemused on kooskõlas varasemate AK ja EK laste narratiivide makrostruktuuri uurimustega (Merritt, Liles 1987, 1989), toetades seisukohta, et vahendatud jutustus toob vahendamata jutustustega võrreldes paremini esile AK laste madalamad tekstiloomeoskused.

Kolmandaks eeldasime, et eelnevalt mudeldatud vahendamata jutustus eristab EK ja AK rühmi paremini kui eelneva mudelita vahendamata jutustus: oletasime, et narratiivide makrostruktuur paraneb mudeldamise tulemusena enam EK lastel, lausetasandi näitajate osas me olulisi muutusi ei eeldanud. Hüpotees leidis kinnitust LP, IÜH ja NKI osas, GVS osas mitte. Nimelt selgus, et näidisjutu esitamisel ei olnud mõju LP-le kummaski kõnearengu taseme rühmas, grammatikavigade langustrend esines aga hoopis AK laste rühmas. Nagu eelnevalt põhjendatud, on üks võimalik seletus ülesande ebapiisav mõistmine 1. jutustuse koostamisel AK rühmas. IÜH tõusis EK laste jutustustes mudeldamise tagajärjel olulisel määral, AK rühmas aga mitte. Ka NKI oli EK laste eelnevalt mudeldatud vahendamata narratiivides oluliselt suurem, võrreldes eelnevalt mudeldamata jutustustega. AK rühmas jäid tulemused vastuoluliseks: rühmas B NKI tõusis, rühmas A jäi samaks. Hoolimata ebapiisavast statistilisest tõestusest NKI osas (mis võib olla tingitud väga väikestest AK alarüh- 
madest), on tulemused siiski kooskõlas Elizabeth Peña jt (2006) uurimusega, kus leiti, et jutustamisele eelneval narratiivi formaadi õpetamisel on positiivne mõju eelkõige EK laste tekstiloomele makrostruktuuri tasandil ning AK lapsed õpivad mudeldamisest vähem. Eri viisil jutustatud narratiivide mikrostruktuuri analüüs näitas, et kuigi lausungite keskmist pikkust näidisjutu esitamine ei mõjutanud, oli sellel positiivne efekt lausungite grammatilisele õigsusele AK laste rühmas.

Käesoleva töö väärtus seisneb laste tekstiloomeoskuste ja eri jutustamisviiside seostamises, olles abiks logopeedidele alakõne diagnostika meetodite valikul. Tulemuste paikapidavust tuleks siiski edaspidi kontrollida suuremal valimil, seda eelkõige AK laste osas. Tulemuste alusel võib kinnitada, et narratiivid võimaldavad saada olulist informatsiooni laste kõnearengu taseme kohta. Jutustamisoskuse hindamiseks narratiivi mikrostruktuuri tasandil sobivad kõigil kolmel viisil jutustatud narratiivid, makrostruktuuri tasandil on sobivaim vahendatud narratiiv, millele järgneb eelnevalt mudeldatud vahendamata narratiiv. Võimalikult täpse ülevaate saamiseks lapse kõnearengu tasemest tuleks siiski kombineerida erinevaid jutustamisviise ning narratiivseid ülesandeid teiste hindamismeetoditega.

\section{Viidatud kirjandus}

Adamka, Aive 2008. 6-8 aasta vanuste laste suuliste jutustuste makrostruktuur. Magistritöö. Tartu: Tartu Ülikool.

Argus, Reili 2008. Eesti keele muutemorfoloogia omandamine. Tallinna Ülikooli humanitaarteaduste dissertatsioonid, 19. Tallinn: TLÜ Kirjastus.

Bishop, Dorothy V. M.; Donlan, Chris 2005. The role of syntax in encoding and recall of pictorial narratives: Evidence from specific language impairment. - British Journal of Developmental Psychology, 23, 25-46. doi:10.1348/026151004X20685

Bishop, Dorothy V. M. 1997. Uncommon Understanding: Development and Disorders of Language Comprehension in Children. Hove: Psychology Press.

Botting, Nicola 2002. Narrative as a tool for the assessment of linguistic and pragmatic impairments. - Child Language Teaching and Therapy, 18, 1-21. doi:10.1191/0265659002ct2240a

Bruner, Jerome 1985. Narrative and paradigmatic modes of thought. - Elliot Eisner (Ed.). Learning and Teaching the Ways of Knowing. Chicago: University of Chicago Press, 97-115.

Cohen, Louis; Manion, Laurence; Morrison, Keith 2007. Research Methods in Education. London, New York: Routledge.

Fey, Marc E.; Catts, Hugh W.; Proctor-Williams, Kerry; Tomblin, J. Bruce; Zhang, Xuyang 2004. Oral and written story composition skills of children with language impairment. - Journal of Speech, Language, and Hearing Research, 47, 1301-1318. doi:10.1044/1092-4388(2004/098)

Hayward, Denyse V.; Gillam, Ronald B.; Lien, Phuong 2007. Retelling a script-based story: Do children with and without language impairments focus on script and story elements? American Journal of Speech-Language Pathology, 16, 235-245. doi:10.1044/10580360(2007/028)

Hayward, Denyse V.; Schneider, Phyllis 200o. Effectiveness of teaching story grammar knowledge to pre-school children with language impairment: An exploratory study. - Child Language Teaching and Therapy, 16, 255-284. doi:10.1191/026565900680410215

Hughes, Diana; McGillivray, LaRae; Schmidek, Mark 1997. Guide to Narrative Language: Procedures for Assessment. Eau Claire, Wisconsin: Thinking Publications. 
John, Shonna F.; Lui, Mariko; Tannock, Rosemary 2003. Children's story retelling and comprehension using a new narrative resource. - Canadian Journal of School Psychology, 18, 91-113. doi:10.1177/082957350301800105

Justice, Laura M.; Bowles, Ryan P.; Kaderavek, Joan N.; Ukrainetz, Teresa A.; Eisenberg, Sarita L.; Gillam, Ronald B. 2006. The index of narrative microstructure: A clinical tool for analyzing school-age children's narrative performances. - American Journal of Speech-Language Pathology, 15, 177-191. doi:10.1044/1058-0360(2006/017)

Karlep, Karl 1997. Eesti vajab kõnepuuete ühtset logopeedia-klassifikatsiooni. - Eripedagoogika: Logopeedia ja Emakeel, 4-15.

Karlep, Karl 2003. Kõnearendus. Tartu: Tartu Ülikooli Kirjastus.

Labov, William 1972. Language in the Inner City: Studies in the Black English Vernacular. Philadelphia: University of Pennsylvania Press.

Leonard, Laurence B. 1998. Children with Specific Language Impairment. Cambridge, MA: MIT Press.

Liles, Betty Z. 1987. Episode organization and cohesive conjunctives in narratives of children with and without language disorder. - Journal of Speech and Hearing Research, 30, 185-196.

Liles, Betty Z.; Duffy, Robert J.; Merritt, Donna D.; Purcell, Sherry L. 1995. Measurement of narrative discourse ability in children with language disorders. - Journal of Speech and Hearing Research, 38, 415-425.

Merritt, Donna D.; Liles, Betty Z. 1987. Story grammar ability in children with and without language disorder: Story generation, story retelling, and story comprehension. - Journal of Speech and Hearing Research, 30, 539-552.

Merritt, Donna D.; Liles, Betty Z. 1989. Narrative analysis: Clinical applications of story generation and story retelling. - Journal of Speech and Hearing Disorders, 54, $429-438$.

Norbury, Courtenay F.; Bishop, Dorothy V. M. 2003. Narrative skills of children with communication impairments. - International Journal of Language and Communication Disorders, 38, 287-313. doi:10.1080/136820310000108133

Padrik, Marika 2006. Milles seisneb kõnearengu puude spetsiifilisus? - Eripedagoogika: Logopeedia ja Emakeel, 26, 13-20.

Pajuste, Maret 2007. Lausungite keeleline seostamine 1. klassi eakohase arenguga ja õpiraskustega õpilastel pildiseeria järgi jutustades. Magistritöö. Tartu: Tartu Ülikool.

Pankratz, Mary E.; Plante, Elena; Vance, Rebecca; Insalaco, Deborah M. 2007. The diagnostic and predictive validity of the Renfrew Bus Story. - Language, Speech, and Hearing Services in Schools, 38, 390-399. doi:10.1044/0161-1461(2007/040)

Pearce, Wendy M.; McCormack, Paul F.; James, Deborah G. H. 2003. Exploring the boundaries of SLI: Findings from morphosyntactic and story grammar analyses. - Clinical Linguistics and Phonetics, 17, 325-334. doi:10.1080/0269920031000080019

Peña, Elizabeth D.; Gillam, Ronald B.; Malek, Melynn; Ruiz-Felter, Roxanna; Resendiz, Maria; Fiestas, Christine; Sabel, Tracy 2006. Dynamic assessment of school-age children's narrative ability: An experimental investigation of classification accuracy. - Journal of Speech, Language, and Hearing Research, 49, 1037-1057. doi:10.1044/10924388(2006/074)

Petersen, Douglas B.; Gillam, Sandra L.; Gillam, Ronald B. 2008. Emerging procedures in narrative assessment: The index of narrative complexity. - Topics in Language Disorders, 28, 115-130.

Peterson, Carole; Dodsworth, Pamela 1991. A longitudinal analysis of young children's cohesion and noun specification in narratives. - Journal of Child Language, 18, 397-415. doi:10.1017/So305000900011120

Reilly, Judy; Losh, Molly; Bellugi, Ursula; Wulfeck, Beverly 2004. "Frog, where are you?" Narratives in children with specific language impairment, early focal brain injury, 
and Williams syndrome. - Brain and Language, 88, 229-247. doi:10.1016/Soo93934X(03)00101-9

Reuterskiöld Wagner, Christina; Sahlén, Birgitta; Nettelbladt, Ulrika 1999. What's story? Narration and comprehension in Swedish preschool children with language impairment. - Child Language Teaching and Therapy, 15, 113-137.

RHK-10 Psüühika- ja käitumishäired. Kliinilised kirjeldused ja diagnostilised juhised. Tõlge eesti keelde. Toim. Veiko Vasar. Tartu: TÜ Kirjastus.

Ripich, Danielle N.; Griffith, Penny L. 1988. Narrative abilities of children with learning disabilities and nondisabled children: Story structure, cohesion, and propositions. Journal of Learning Disabilities, 21, 165-173. doi:10.1177/002221948802100309

Ruul, Riina 2009. 5-6-aastaste laste jutustuste sidusus ja selle hindamine. Magistritöö. Tartu: Tartu Ülikool.

Schneider, Phyllis; Hayward, Denyse; Dubé, Rita V. 2006. Storytelling from pictures using the Edmonton Narrative Norms Instrument. - Journal of Speech-Language Pathology and Audiology, 30, 224-238.

Scott, Cheryl M.; Windsor, Jennifer 2000. General language performance measures in spoken and written narrative and expository discourse of school-age children with language learning disabilities. - Journal of Speech, Language, and Hearing Research, $43,324-339$.

Shapiro, Lauren R.; Hudson, Judith A. 1991. Tell me a make-believe story: Coherence and cohesion in young children Picture-elicited narratives. - Developmental Psychology, 27, 960-974. doi:10.1037/0012-1649.27.6.960

Sleight, Christine C.; Printz, Philip M. 1985. Use of abstracts, orientations, and codas in narration by language-disordered and nondisordered children. - Journal of Speech and Hearing Disorders, 50, 361-371.

Stein, Nancy L.; Glenn, Christine G. 1979. An analysis of story comprehension in elementary school children. - Roy O. Freedle (Ed.). New Directions in Discourse Processing, 2. Norwood, NJ: Ablex, 53-120.

Tilstra, Janet; McMaster, Kristen 2007. Productivity, fluency, and grammaticality measures from narratives: Potential indicators of language proficiency? - Communication Disorders Quarterly, 29, 43-53. doi:10.1177/1525740108314866

Ukrainetz, Teresa A.; Justice, Laura M.; Kaderavek, Joan N.; Eisenberg, Sarita L.; Gillam, Ronald B.; Harm, Heide M. 2005. The development of expressive elaboration in fictional narratives. - Journal of Speech, Language, and Hearing Research, 48, 1363-1377. doi:10.1044/1092-4388(2005/095)

Vacha-Haase, Tammi; Thompson, Bruce 2004. How to estimate and interpret various effect sizes. - Journal of Counseling Psychology, 51, 473-481. doi:10.1037/00220167.51.4.473

Vance, Maggie 2008. Short-term memory in children with developmental language disorder. - Courtenay F. Norbury, J. Bruce Tomblin, Dorothy V. M. Bishop (Eds.). Understanding Developmental Language Disorders: From Theory to Practice. New York: Psychology Press, 23-38.

van Dijk, Teun A.; Kintsch, Walter 1983. Strategies of Discourse Comprehension. New York: Academic Press. 
Lisa. Narratiivi komplekssuse indeksi kodeerimisjuhis

(Petersen jt 2008 järgi)

\begin{tabular}{|c|c|c|c|c|}
\hline $\begin{array}{l}\text { Narratiivi } \\
\text { element }\end{array}$ & 0 punkti & 1 punkt & 2 punkti & 3 punkti \\
\hline Tegelased & $\begin{array}{l}\text { Peategelasi ei } \\
\text { ole nimetatud } \\
\text { või on kasutatud } \\
\text { asesõnu. }\end{array}$ & $\begin{array}{l}\text { Sisaldab vähe- } \\
\text { malt ühte pea- } \\
\text { tegelast, mis on } \\
\text { märgitud mit- } \\
\text { tespetsiifiliselt. }\end{array}$ & $\begin{array}{l}\text { Sisaldab ühte } \\
\text { peategelast, kes } \\
\text { on märgitud } \\
\text { spetsiifilise } \\
\text { nimega. }\end{array}$ & $\begin{array}{l}\text { Sisaldab rohkem } \\
\text { kui ühte peate- } \\
\text { gelast, kes on } \\
\text { märgitud spetsii- } \\
\text { filise nimega. }\end{array}$ \\
\hline Taustakirjeldus* & $\begin{array}{l}\text { Ei ole viidatud } \\
\text { ajale, kohale ega } \\
\text { tegevusele. }\end{array}$ & $\begin{array}{l}\text { Sisaldab ühte vii- } \\
\text { det ajale, kohale } \\
\text { või tegevusele. }\end{array}$ & $\begin{array}{l}\text { Sisaldab kahte } \\
\text { või enamat vii- } \\
\text { det ajale, kohale } \\
\text { või tegevusele. }\end{array}$ & \\
\hline $\begin{array}{l}\text { Käivitav } \\
\text { sündmus }\end{array}$ & $\begin{array}{l}\text { Sündmust ega } \\
\text { probleemi ei ole } \\
\text { nimetatud. }\end{array}$ & $\begin{array}{l}\text { Sisaldab vä- } \\
\text { hemalt ühte } \\
\text { otsest viidet } \\
\text { sündmusele või } \\
\text { probleemile, mis } \\
\text { võiks kutsuda } \\
\text { esile tegelase } \\
\text { reaktsiooni, kuid } \\
\text { puudub tegelase } \\
\text { reaktsioon, mis } \\
\text { oleks otseselt } \\
\text { seotud selle } \\
\text { sündmusega. }\end{array}$ & $\begin{array}{l}\text { Sisaldab vähe- } \\
\text { malt ühte otsest } \\
\text { viidet sündmu- } \\
\text { sele või problee- } \\
\text { mile, mis kutsub } \\
\text { esile tegelase } \\
\text { reaktsiooni. }\end{array}$ & $\begin{array}{l}\text { Kaks või enam } \\
\text { eraldi viidatud } \\
\text { sündmust või } \\
\text { probleemi, mis } \\
\text { kutsuvad esile } \\
\text { tegelase reakt- } \\
\text { siooni. }\end{array}$ \\
\hline Sisemine vastus & $\begin{array}{l}\text { Ei ole otsest väl- } \\
\text { jendit tegelase } \\
\text { psühholoogilise } \\
\text { seisundi kohta. }\end{array}$ & $\begin{array}{l}\text { Üks otsene } \\
\text { väljend tegelase } \\
\text { psühholoogilise } \\
\text { seisundi kohta, } \\
\text { mis ei ole aga } \\
\text { põhjuslikult } \\
\text { seotud käivitava } \\
\text { sündmusega. }\end{array}$ & $\begin{array}{l}\text { Üks või enam } \\
\text { otsest väljendit } \\
\text { tegelase psüh- } \\
\text { holoogilise sei- } \\
\text { sundi kohta, mis } \\
\text { on põhjuslikult } \\
\text { seotud käivitava } \\
\text { sündmusega. }\end{array}$ & \\
\hline Sisemine plaan & $\begin{array}{l}\text { Ei ole otsest } \\
\text { viidet tegelase } \\
\text { plaanile tegutse- } \\
\text { da või lahendada } \\
\text { olukorda. }\end{array}$ & $\begin{array}{l}\text { Üks otsene } \\
\text { väljend, kuidas } \\
\text { tegelane võiks } \\
\text { lahendada olu- } \\
\text { korda. }\end{array}$ & $\begin{array}{l}\text { Kaks otsest } \\
\text { väljendit, kuidas } \\
\text { tegelane võiks } \\
\text { käituda või } \\
\text { lahendada olu- } \\
\text { korda. }\end{array}$ & $\begin{array}{l}\text { Kolm või enam } \\
\text { otsest väljendit, } \\
\text { kuidas tegelane } \\
\text { võiks käituda või } \\
\text { lahendada olu- } \\
\text { korda. }\end{array}$ \\
\hline Tegevus & $\begin{array}{l}\text { Ei sisalda } \\
\text { peategelas(t)e } \\
\text { poolt tehtud } \\
\text { tegevusi. }\end{array}$ & $\begin{array}{l}\text { Sisaldab viiteid } \\
\text { peategelas(t)e } \\
\text { tegevustele, mis } \\
\text { ei ole seotud } \\
\text { käivitava sünd- } \\
\text { musega. }\end{array}$ & $\begin{array}{l}\text { Sisaldab viiteid } \\
\text { peategelas(t)e } \\
\text { tegevustele, } \\
\text { mis on otseselt } \\
\text { seotud käivitava } \\
\text { sündmusega. }\end{array}$ & \\
\hline Takistus & Ei ole takistusi. & $\begin{array}{l}\text { Üks takistus } \\
\text { plaani või } \\
\text { tegevuse } \\
\text { teostumisel. }\end{array}$ & $\begin{array}{l}\text { Kaks takistust } \\
\text { plaani või } \\
\text { tegevuse } \\
\text { teostumisel. }\end{array}$ & \\
\hline
\end{tabular}




\begin{tabular}{|c|c|c|c|c|}
\hline $\begin{array}{l}\text { Narratiivi } \\
\text { element }\end{array}$ & 0 punkti & 1 punkt & 2 punkti & 3 punkti \\
\hline Tagajärg & $\begin{array}{l}\text { Tegevuse ta- } \\
\text { gajärge ei ole } \\
\text { otseselt väljen- } \\
\text { datud. }\end{array}$ & Üks tagajärg. & Kaks tagajärge. & $\begin{array}{l}\text { Kolm või enam } \\
\text { tagajärge. }\end{array}$ \\
\hline $\begin{array}{l}\text { Jutustuse alguse } \\
\text { ja lõpu markerid } \\
\text { (nt lõpp, oli kord, } \\
\text { elas kord jne) }\end{array}$ & Ei ole markereid & Üks marker. & $\begin{array}{l}\text { Kaks või enam } \\
\text { markerit. }\end{array}$ & \\
\hline $\begin{array}{l}\text { Ajamarkerid* } \\
\text { (nt kui, siis, peale } \\
\text { seda, kohe jne) }\end{array}$ & $\begin{array}{l}\text { Ei ole ajamarke- } \\
\text { reid. }\end{array}$ & $\begin{array}{l}\text { Üks ajamarker } \\
\text { või ajamarkeri } \\
\text { siis korduv kasu- } \\
\text { tamine. }\end{array}$ & $\begin{array}{l}\text { Kaks või enam } \\
\text { ajamarkerit. }\end{array}$ & \\
\hline $\begin{array}{l}\text { Põhjusseoseid } \\
\text { markeerivad } \\
\text { keelendid } \\
\text { (nt sellepärast, } \\
\text { sest, sellepärast } \\
\text { et jne) }\end{array}$ & $\begin{array}{l}\text { Ei ole põhjusse- } \\
\text { oseid markeeri- } \\
\text { vaid keelendeid. }\end{array}$ & $\begin{array}{l}\text { Üks põhjusseost } \\
\text { markeeriv kee- } \\
\text { lend. }\end{array}$ & $\begin{array}{l}\text { Kaks või enam } \\
\text { põhjusseost } \\
\text { markeerivat } \\
\text { keelendit. }\end{array}$ & \\
\hline Dialoog & Ei ole dialoogi & $\begin{array}{l}\text { Üks tegelane } \\
\text { ütleb midagi. }\end{array}$ & $\begin{array}{l}\text { Kaks või enam } \\
\text { tegelast vestle- } \\
\text { vad. }\end{array}$ & \\
\hline $\begin{array}{l}\text { Jutustajapoolsed } \\
\text { hinnangud }\end{array}$ & $\begin{array}{l}\text { Ei ole hinnan- } \\
\text { guid. }\end{array}$ & Üks hinnang. & $\begin{array}{l}\text { Kaks või enam } \\
\text { hinnangut. }\end{array}$ & \\
\hline
\end{tabular}

* Märkus. Kodeerimissüsteemi on käesolevas uurimuses kohandatud.

Piret Soodla (Tallinna Ülikool, Tartu Ülikool) uurimistöö valdkonnad on suulise ja kirjaliku kõne areng, selle seosed akadeemilise edukusega ning vaimsete võimetega, kõne arengu mahajäämuse diagnostika.

piret.soodla@ut.ee

Eve Kikase (Tallinna Ülikool, Tartu Ülikool) uurimistöö valdkonnad on kooliõpetuse mõju mõtlemisele, laste ja täiskasvanute mõisted, erivajadustega laste võimed ja nende hindamine, laste agressiivsus ja selle areng.

eve.kikas@ut.ee

Renate Pajusalu (Tartu Ülikool) uurimisvaldkonnad on eesti keele semantika ja pragmaatika, esimese ja teise keele omandamise erinevad aspektid.

renate.pajusalu@ut.ee

Aive Adamka (Tartu Hiie Kool) töötab eesti keele ja kõneravi õpetajana, uurib tekstiloomeoskuste arengut lastel.

Aive.Adamka@mail.ee

Sirli Parmi (Tartu Ülikool) uurimisvaldkonnad on lapse keele omandamine, leksikaalne semantika. sirli.parm@ut.ee 


\title{
SELF-GENERATED AND RETOLD NARRATIVES AS A TOOL OF LANGUAGE ASSESSMENT
}

\author{
Piret Soodla, Eve Kikas, Renate Pajusalu, \\ Aive Adamka, Sirli Parm \\ Tallinn Univerity, University of Tartu, Tartu Hiie School
}

The article explores oral narratives of 6-7year old typically developing (TD) children $(N=162)$ and children with language impairment (LI) $(N=27)$. Narratives were elicited by three methods: generated stories without previous narrative model and with previous narrative model, and retold stories. The analysis comprises narrative microstructure (mean length of utterances, grammatical errors) and macrostructure (quantity of information units, complexity). The purpose is to find out which method suits best for the identification of LI in language assessment. The results show that for microstructure level, all three kinds of stories distinguish children with LI from their peers with TD. For macrostructure level, retold stories enable better distinction between LI and TD as compared to self-generated stories, likewise generated stories with previous narrative model, as compared to stories without previous model.

Keywords: linguistic development, speech disorders, narrative, syntax, morphology, textual structure, Estonian language 